\title{
Study of fluvial water treatability using $\gamma$-polyglutamic acid based biopolymer coagulant
}

\author{
VALQUÍRIA CAMPOS, JANAÍNA M.F. DOMINGOS, DIEGO N. DOS ANJOS and VIVIAN S. LIRA
}

Universidade Estadual Paulista “Júlio de Mesquita Filho"/UNESP, Instituto de Ciência e Tecnologia de Sorocaba/ICTS, Avenida Três de Março, 511, Alto da Boa Vista, 18087-180 Sorocaba, SP, Brazil

Manuscript received on June 18, 2018; accepted for publication on March 27, 2019

\begin{abstract}
How to cite: CAMPOS V, DOMINGOS JMF, ANJOS DN AND LIRA VS. 2019. Study of fluvial water treatability using $\gamma$-polyglutamic acid based biopolymer coagulant. An Acad Bras Cienc 91: e20190051. DOI 10.1590/00013765201920190051.

Abstract: Successful treatment of surface water for public use requires the evaluation of raw water and coagulant efficacy. The purpose of water treatment is to remove impurities, allowing its quality to be classified to meet the needs of the population. The conditions of urban rivers that flow though the city of São Paulo, which were already undergoing major transformations, particularly due to intense urbanization, have deteriorated further due to the precariousness of basic sanitation and increasing environmental pollution.This study focused on an analysis of the efficiency of PGa21Ca, a water purification product, in the treatment of Pinheiros River water, based on coagulation-flocculation and sedimentation tests. The biopolymer PG $21 \mathrm{Ca}$ reduced in the order of $100 \%$ the total phosphorus. The best sedimentation velocity for the coagulant under study was $1 \mathrm{~cm} \mathrm{~min}^{-1}$. The PG $\alpha 21 \mathrm{Ca}$ performed well in the removal of turbidity and apparent color, with residual turbidity of $1.84 \mathrm{NTU}, 96.95 \%$ removal of apparent color, and little change in the $\mathrm{pH}$ of the medium.
\end{abstract}

Key words: $\gamma$-polyglutamic acid, coagulant, coagulation-flocculation and sedimentation tests, urban river, São Paulo.

\section{INTRODUCTION}

The Metropolitan Region of São Paulo (MRSP) is located in southeastern Brazil and is one of the world's largest urban agglomerations. Rapid economic development and intense urbanization throughout the country have led to serious problems in the MRSP, with a high demand for water supply, the need for more efficient sewage treatment, and significant losses in the environmental quality of its surface water bodies.

Correspondence to: Valquíria Campos

E-mail: v.campos@unesp.br

ORCid: https://orcid.org/0000-0002-2974-6928
Among the water courses that make up São Paulo's hydrographic network, the Pinheiros River is one of the most important since the city's emergence, when this river was the main means of transportation of its earliest populations.

The Pinheiros River is in a state of significant environmental vulnerability, with several stretches receiving raw industrial and residential wastewater every day. The tributaries on the left bank of the Pinheiros River down to where it flows into the Tietê River are Jaguaré Creek, Pirajuçara River, Poá Creek and Embú-Guaçu River. Its tributaries on the right bank are the Belini, Corujas, Verde, Iguatemi, Sapateiro, Uberaba, Traição, Água 
Espraiada, Morro do S, Ponte Baixa, Zavuvu and Olaria streams. The river's drainage basin covers 270 square kilometers and the river became disfigured by the construction of the Pinheiros River canal, which stretches for $25 \mathrm{~km}$ from the Pedreira pumped-storage hydroelectric power station to the point known as Paredão do Retiro. Due to the hydrological conditions artificially imposed on the Pinheiros River, which make it difficult for natural self-purification phenomena to occur and which are aggravated by the effects of diffuse pollution throughout the Upper Tietê basin, this river is extremely polluted, often exuding a foul odor felt by passersby and by those who live in its proximities.

In 2001, a pilot plant was built using the flotation technique in an attempt to clean up the Pinheiros River, aiming to pump its water into the Billings Reservoir. However, although the tests indicated an improvement in the water quality of the Pinheiros River, its recovery did not suffice to allow the river water to be pumped into reservoir, since the quality achieved in the tests failed to meet the legal requirements of environmental and public health standards. Thus, there seems to be no shortterm solution for cleaning up this water, not only for its use in electricity generation but also from the sanitary and even aesthetic standpoints.

The main processes in conventional treatments are coagulation and flocculation. Coagulation consists of mixing chemicals, usually inorganic coagulants, into the water under intense agitation in order to electrically destabilize impurities (suspended solids, colloids, algae, bacteria), causing them to agglomerate. In the flocculation step, agitation is slower and longer, aiding the formation of flakes, which settle and are removed by filtration (Pritchard et al. 2010). In Brazil, aluminum sulfate $\left(\mathrm{Al}_{2}\left(\mathrm{SO}_{4}\right)_{3}\right)$ and aluminum polychloride (APC) $\left(\mathrm{Aln}(\mathrm{OH}) \mathrm{m}\left(\mathrm{Cl}_{3}\right) \mathrm{n}-\mathrm{m}\right)$ are the aluminum based products most commonly used for coagulation in water treatment plants. Due to risks to human health and the environment, such as the appearance of degenerative diseases, e.g., Alzheimer's, associated with the use of aluminum salts in water treatment (Bondy 2010, Dzulfakar et al. 2011), alternatives to these products have been sought, such as biopolymers. These can be used in separately or in combination with traditional inorganic coagulants, thus reducing operational costs, as well as impacts on the environment and human health (Huang et al. 2015). Campos et al. (2016) evaluated the efficiency of PGa21Ca in the water treatment plant (WTP) of Salto de Pirapora, São Paulo, where the commercial product proved efficient in the removal of turbidity and apparent color, showing residual turbidity of 1.93 NTU and $96.89 \%$ removal of apparent color, with little change in the $\mathrm{pH}$ of the medium, thus proving its effectiveness in public water supply treatment.

Gamma-polyglutamic acid ( $\gamma$-PGA) is a watersoluble, biodegradable, biocompatible and nontoxic anionic biopolymer obtained from bacteria of the genus Bacillus through fermentative processes (Sung et al. 2005, Bajaj and Singhal 2011, Shih et al. 2011). Some companies such as Ajinomoto Co., Nippon Poly-Glu Co. and Natto Biosciences. produce $\gamma$-PGA commercially. In view of the above, the purpose of this study was to analyse the efficiency of the commercial biopolymer PGa21Ca in coagulation-flocculation processes and in the separation of solids from the liquid phase by sedimentation, in order to reach raw water quality standards of the Pinheiros River, located in the urban region of the city of São Paulo, Brazil.

\section{MATERIALS AND METHODS}

A water sample was collected from the Pinheiros River in the city of São Paulo, in the dry season, September 2017. The collection point was near the mouth of the river to determine the load discharged into the Tietê River (Figure 1). The raw water sample were stored in polyethylene 


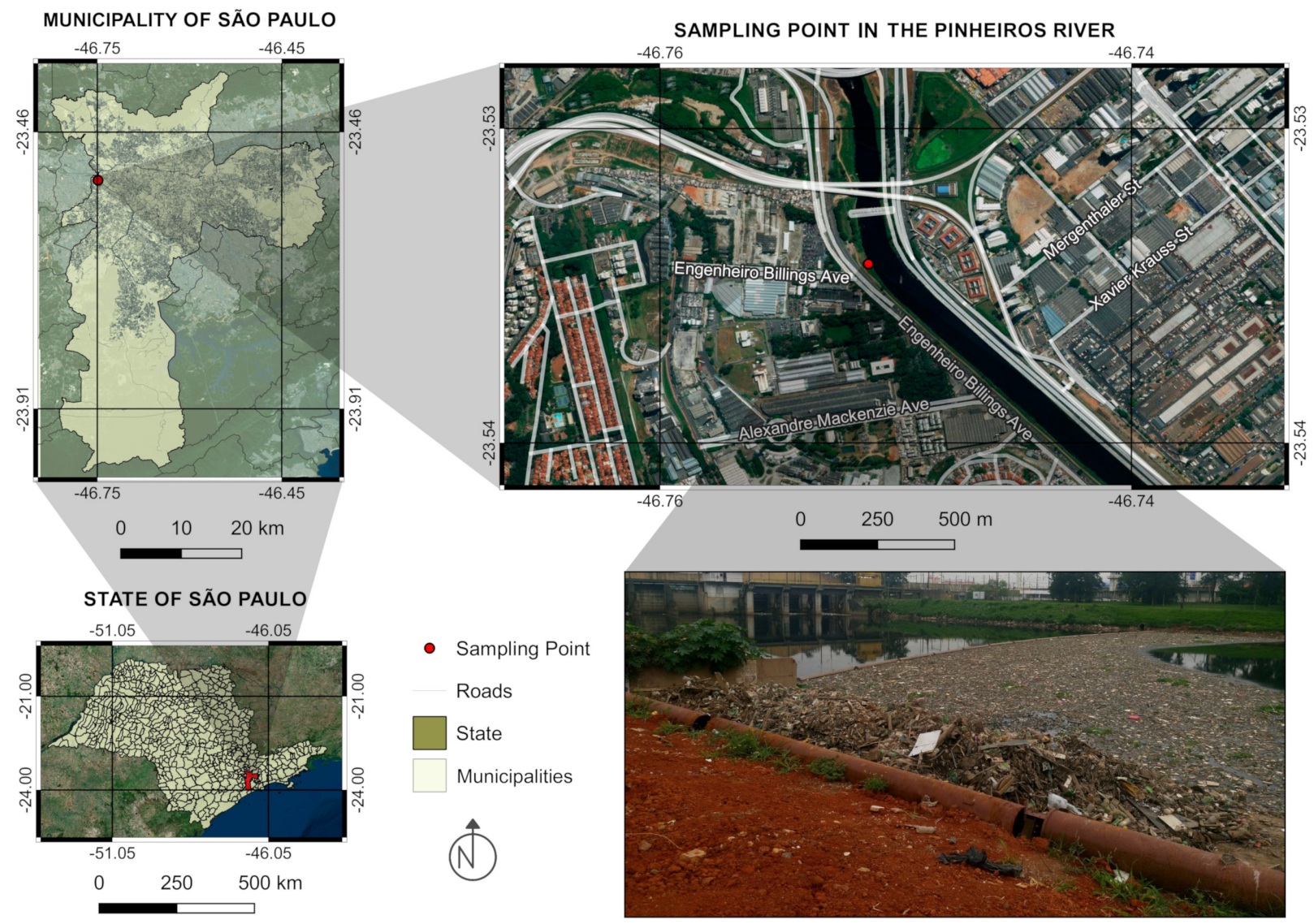

Satellite Image: Landsat/NASA and Digital Globe 2014 | Datum: SIRGAS 2000 | Municipal Boundaries: IBGE 2014 | Roads: Open Street Map 2017 | Created in: 2017

Figure 1 - Location map of Pinheiros River, São Paulo, Brazil. The image shows the water collection point near the river's mouth, with clearly visible garbage carried by stormwater runoff and various types of wastes discarded into the river by the population, contributing to the frequent flooding events in the city.

bottles and refrigerated until they were subjected to physicochemical analysis and jar testing, followed the recommendations of ISO 5667-3 (2012). Initial analyzes were performed usinga Horiba U-50 series multiparameter water quality checker equipped with a multisensor probe that can measure up to 11 parameters simultaneously. The Pinheiros River is classified as a Class 4 river, according to São Paulo State Decree No. 10,755/77. The purpose of categorizing water bodies into classes is to establish the target water quality that must necessarily be reached or maintained over time in a given section of the water body, according to prevailing or intended uses, based on the quality the water body must have to meet more restrictive uses. Water from class 2 rivers is distributed for human consumption after conventional treatment (CONAMA 2005). In 2017 the Government of the State of São Paulo launched the reclassification project for the Pinheiros River, which focuses on the gradual cleaning of river water to reclassify it from class 4 , the worst level of pollution, to class 2. Proposals should involve conventional technologies, methods and/or treatment systems.

The PGa21Ca powder came from Nippon Poly-Glu Co. Ltd., recommended for use of 50 to $100 \mathrm{mg} \mathrm{L}^{-1}$. The product's typical flocculation time, whose initial turbidity of 100 NTU is 15 minutes, results in a final turbidity of $<1$ NTU. The coagulant was added directly to the jars, as recommended 
by the manufacturer, to prevent reactions with other components of the formulation, such as calcium and aluminum sulfates, forming insoluble polyglutamates. A scanning electron microscopy (SEM) analysis was performed using a LEO 440i microscope coupled to an energy dispersive X-ray spectrometer (EDS).

Raw water cations were determined by means of inductively coupled plasma-optical emission spectroscopy (ICP-OES), using a SPECTRO ARCOS ICP-OES analyzer. Anions were determined simultaneously by high performance liquid chromatography (HPLC), using a PerkinElmer model 430D chromatograph.

An Ethik Technology model 218-6 LDB jar tester was used in the jar test, comprising six jars with an internal volume of two liters. In the jar test, the speed gradient $(\mathrm{G})$ can be adjusted in the range of 10 to $1200 \mathrm{~s}^{-1}$, with the edition of up to four different programs, each comprising 12 segments. The tests were conducted according to the procedures of the Standard Methods for the Examination of Water and Wastewater (APHA 2012).

\section{RESULTS AND DISCUSSION}

According to the material safety data sheet (MSDS) of PGa21Ca, its formulation contains 70 to $80 \%$ calcium sulfate and 10 to $20 \%$ calcium carbonate, with $<10 \% \gamma$-polyglutamic acid, $<10 \%$ sodium carbonate, $<10 \%$ aluminum sulfate and $<10 \%$ of other components. However, an elemental analysis of $\mathrm{PG} \alpha 21 \mathrm{Ca}$ based on the monomer $\mathrm{C}_{5} \mathrm{H}_{7} \mathrm{NO}_{3}$ indicated that its formulation contained an estimated content of $5.26 \%$ of the active ingredient $\gamma$-polyglutamic acid (Campos et al. 2016). The PGo21Ca was examined by SEM, which revealed a morphology of gypsum and the mineral was also identified by X-ray diffraction (XRD) (Campos et al. 2016).

Table I describes the physical and chemical parameters of the raw and treated water from
Pinheiros River in the dry season, comparing them with that reported by Cunha (2010), the guidelines and legal limits established by Conselho Nacional de Meio Ambiente (CONAMA) under Resolution No. 357/2005 for the class 4 surface waters and the USEPA Surface Quality Criteria for Class 2 and Class 4 waters (USEPA 2018). The poor water quality of the Pinheiros River is indicated by its high turbidity and intense odor of gases such as $\mathrm{CH}_{4}$ and $\mathrm{H}_{2} \mathrm{~S}$. According to Rocha (1991), highly complex organic pollutants are discharged into both the Pinheiros and Tietê rivers, as well as numerous inorganic substances from industrial sources, due to the lack of adequate treatment of sanitary sewage and industrial effluents in the metropolitan region of São Paulo.

Table I shows changes in $\mathrm{pH}$ after treatment with the biopolymeric coagulant, with $\mathrm{pH}$ decreasing in response to increasing doses of coagulant. Yokoi (1996) stated that $\gamma$-PGA in water causes ionsto increase by neutralizing and stabilizing of negatively charged colloids, generating residual carboxylic groups that are responsible for bridging between suspended particles.

Almost all water bodies contain permissible concentrations of aluminum. However, the Al content was higher after treatment with the biopolymeric coagulant, probably due to the transfer of $\mathrm{Al}$ from the coagulant to the treated water, since the PGo21Ca essentially contains calcium sulfate (87\%) in its formulation, among other chemical compounds (Campos et al. 2016).

According to Guimarães (2017), effective coagulation depends on some factors, the interaction rate between the coagulant $\left(\mathrm{Fe}^{+3}\right.$ and $\left.\mathrm{Al}^{+3}\right)$ and its hydrolysis products, the colloidal particles and their dissolved compounds and, moreover, values of zero zeta potential giving the coagulant an effectiveness when dealing with smaller fractional dimensions or greater porosity of the flake. Guimarães (2017) also emphasizes that the techniques that allow the specific evaluation of the 
TABLE I

Physicochemical parameters of raw and treated water from the Pinheiros River in the dry season.

\begin{tabular}{|c|c|c|c|c|c|c|c|}
\hline \multirow[b]{2}{*}{ Parameters } & \multirow[b]{2}{*}{ Unit } & \multicolumn{2}{|c|}{ This study } & \multirow{2}{*}{$\begin{array}{l}\text { Cunha } \\
\text { et al. } 2010\end{array}$} & \multirow{2}{*}{$\begin{array}{c}\text { Conama } \\
357 / 2005 \\
\text { Class } 4\end{array}$} & \multirow{2}{*}{$\begin{array}{c}\text { USEPA* }^{*} \\
(2018) \\
\text { Class } 4\end{array}$} & \multirow{2}{*}{$\begin{array}{c}\text { USEPA* } \\
(2018) \\
\text { Class } 2\end{array}$} \\
\hline & & Raw water & $\begin{array}{c}\text { Treated water } \\
\left(20 \mathrm{~g} \mathrm{~L}^{-1} \text { of } \gamma \text {-PGA) }\right.\end{array}$ & & & & \\
\hline Aluminum & $\mathrm{mg} \mathrm{L}^{-1}$ & 0.21 & 4.0 & 0.5 & 0.2 & - & $\leq 1.50$ \\
\hline Chromium & $\mathrm{mg} \mathrm{L}^{-1}$ & 0.01 & $<0.010$ & 0.03 & 0.05 & $\leq 0.011$ & $\leq 0.05$ \\
\hline Copper & $\mathrm{mg} \mathrm{L}^{-1}$ & 0.04 & $<0.005$ & 0.05 & 0.013 & $\leq 0.50$ & $\leq 0.004$ \\
\hline Iron & $\mathrm{mg} \mathrm{L}^{-1}$ & 1.2 & $<0.100$ & 17.2 & 5.0 & $\leq 1.00$ & $\leq 0.30$ \\
\hline Lead & $\mu \mathrm{g} \mathrm{L}^{-1}$ & $<0.010$ & $<0.010$ & 0.03 & 0.01 & $\leq 50.0$ & $\leq 8.50$ \\
\hline Manganese & $\mathrm{mg} \mathrm{L}^{-1}$ & 0.16 & 0.125 & 0.63 & 0.5 & - & $\leq 0.10$ \\
\hline Zinc & $\mathrm{mg} \mathrm{L}^{-1}$ & 0.04 & $<0.010$ & 0.16 & 5,0 & $\leq 1.00$ & $\leq 0.86$ \\
\hline Total phosphorus & $\mathrm{mg} \mathrm{L}^{-1}$ & 4.1 & $<0.015$ & 5.4 & 0.05 & - & $\leq 0.0001$ \\
\hline Nitrogen ammonia & $\mathrm{mg} \mathrm{L}^{-1}$ & 45 & 41 & 117 & $5.6-13.3$ & - & - \\
\hline $\mathrm{pH}$ & - & 7.1 & 6.7 & 10.7 & $6.0-9.0$ & $6.0-8.5$ & $6.0-8.5$ \\
\hline $\begin{array}{c}\text { Electrical } \\
\text { conductivity }\end{array}$ & $\mu \mathrm{S} \mathrm{cm}{ }^{-1}$ & 2580 & 0.62 & 1,350 & - & - & - \\
\hline Dissolved oxygen & $\mathrm{mg} \mathrm{L}^{-1}$ & 5.83 & 4.61 & 4.8 & $>2.0$ & $\geq 4.0$ & - \\
\hline Temperature & ${ }^{\circ} \mathrm{C}$ & 24.3 & 22.6 & 33 & - & - & - \\
\hline $\begin{array}{l}\text { Thermotolerant } \\
\text { Coliform }\end{array}$ & $\begin{array}{l}\mathrm{NMP} / 100 \\
\mathrm{~mL}\end{array}$ & $1,6 \times 10^{4}$ & $1,6 \times 10^{4}$ & $1,2 \times 10^{7}$ & - & - & $\leq 800$ \\
\hline Turbidity & NTU & 233.4 & 1.84 & 356 & - & $\leq 29$ & $\leq 29$ \\
\hline Apparent color & $\mathrm{uH}$ & 886 & 27.47 & 2,58 & 75 & - & - \\
\hline $\begin{array}{l}\text { Total dissolved } \\
\text { solids }\end{array}$ & $\mathrm{mg} \mathrm{L}^{-1}$ & 1571 & 217 & 544 & 500 & - & - \\
\hline
\end{tabular}

*No limit established.

efficiency of the coagulation-flocculation treatment process are: zeta potential $\mathrm{PZ}, \mathrm{pH}$, operational conditions and effluent characteristics. Reasons that may explain the increase in $\mathrm{Al}$ concentration in the treated water of the present study.

The presence of phosphorus exceeding the legally established limit may be attributed to eutrophication resulting from inputs from point sources of pollution, which negatively affect the river's ecosystem. In this study, a phosphorus concentration of $4.1 \mathrm{mg} \mathrm{L}^{-1}$ was found in the Pinheiros River, in comparison to the concentrations of $5.4 \mathrm{mg} \mathrm{L}^{-1}$ reported by Cunha et al. (2010). The treatment with PG $221 \mathrm{Ca}$ reduced the total phosphorus content by $100 \%$. Like phosphorus, the indices of ammoniacal nitrogen were high, indicating the incessant discharge of domestic sewage into the river. These findings indicate the low concentration of dissolved oxygen, which greatly limits aquatic life in the Pinheiros River. 
The non-compliance in terms of apparent color is also a strong indicator of eutrophication in the reservoir.

The results presented in Table I show that thermotolerant coliform concentrations did not vary and therefore PGa21Ca was not efficient in reducing fecal contamination. However, Cunha et al. (2010) pointed out that the flotation system showed significant efficiency in the removal of thermotolerant coliforms. The use of PG $\alpha 21 \mathrm{Ca}$ did not appear to reduce the level of sanitary pollution, emphasizing the importance of chemically assisted primary treatment.

As for residual turbidity, the jar tests indicated that the best result was achieved at a sedimentation velocity of $1 \mathrm{~cm} \mathrm{~min}$. In other words, as the sedimentation velocity decreased, so did the residual turbidity. Figure 2 is based on this sedimentation velocity. Raw water from the Pinheiros River showed initial apparent color of $886 \mathrm{uH}$ and turbidity of 233.4 NTU. Figure 2 illustrates the behavior of the coagulant in the treatment of raw water.

The dose of $100 \mathrm{mg} \mathrm{L}^{-1}$ of $\mathrm{PG} \alpha 21 \mathrm{Ca}$ resulted in the removal of $96.95 \% \pm 0.68 \%$ of apparent color and $1.84 \pm 0.12 \mathrm{NTU}$ of residual turbidity. The turbidity and apparent color removal rates ranged from $48 \%$ to $54 \%$ when considering the overall effect of the two flotation stations in series. Figure 2 shows the performance of $\mathrm{PG} \alpha 21 \mathrm{Ca}$ in the dry season, when the most effective dose was $100 \mathrm{mg}$ $\mathrm{L}^{-1}$, given the high turbidity and apparent color of the raw water of the Pinheiros River.

\section{CONCLUSIONS}

Gamma-polyglutamic acid ( $\gamma$-PGA) is a polymeric acid that reacts with calcium and aluminum salts contained in its formulation, as well as with soluble metals that are present in water, forming polyglutamates. These polyglutamates settle readily, adsorbing other inorganic substances and thus purifying the water. Therefore, it is desirable for polyglutamates to be formed only when PGa21Ca is added to water, and not before. The components of $\mathrm{PG} \alpha 21 \mathrm{Ca}$ in powder form are unreactive, so they can be stored for long periods of time.

From the standpoint of potability, the presence of thermotolerant coliforms leaves no doubt about the fecal origin of the contamination, which is very common in waters polluted with animal wastes and sewage. PGa21Ca did not succeed in reducing the thermotolerant coliform concentration. In this case,

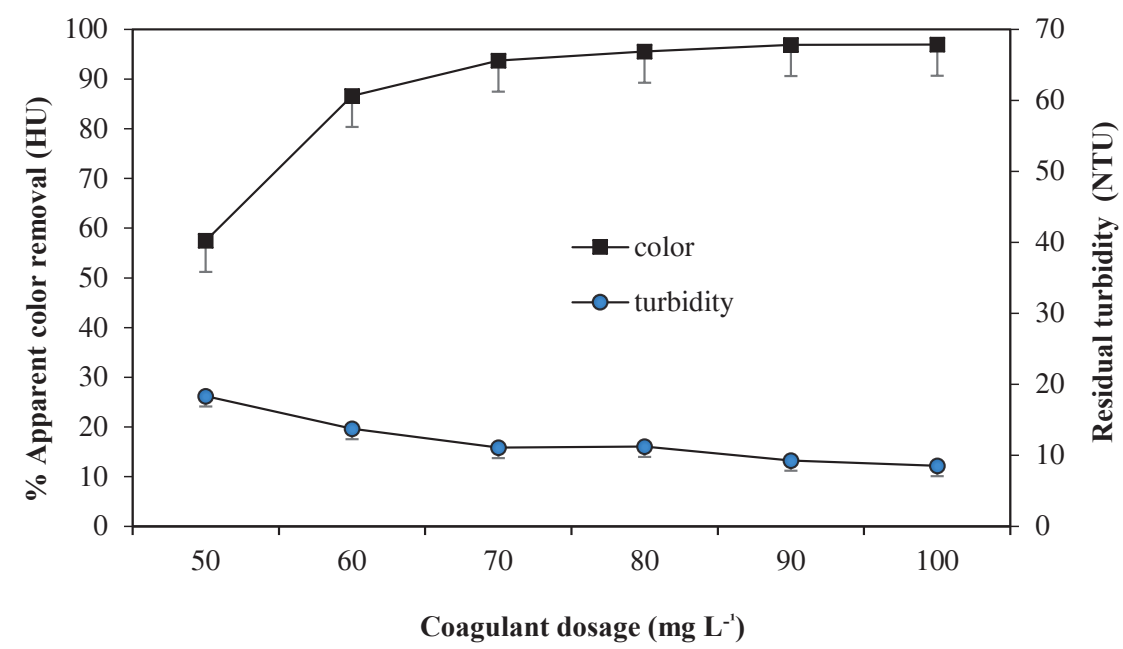

Figure 2 - Residual turbidity and apparent color removal rate of Pinheiros River water treated with $\mathrm{PG} \alpha 21 \mathrm{Ca}\left(\mathrm{Vs} 1 \mathrm{~cm} \mathrm{~min}^{-1}\right)$ in the dry season. 
therefore, measures should be adopted to sanitize and disinfect the water. The Pinheiros River water falls into the category of class 4 , and the main reason for its degradation is probably ascribable to the discharge of domestic sewage.

The use of PG $\alpha 21 \mathrm{Ca}$ did not significantly alter the $\mathrm{pH}$ of the water $(6.7 \pm 0.15)$, due to the increased dose of the product. This can be considered an advantage over traditional coagulants, which require adjustments to correct the $\mathrm{pH}$ to meet potable water standards. Within the dose range, PGo21Ca may transfer part of the Al contained in its formulation to the medium, which explains the increase in aluminum content in the treated water.

This study revealed the remarkable effects of the biopolymer PGa21Ca in the removal of apparent color and turbidity from Pinheiros River water. In addition, treatment with PGo21Ca led to a reduction in the order of $100 \%$ of total phosphorus. The best sedimentation velocity for the coagulant under study was $1 \mathrm{~cm} \mathrm{~min}^{-1}$. In the coagulationflocculation and sedimentation tests of Pinheiros River water, PGa21Ca presented significant apparent color and turbidity removal rates. In the dry season, a dose of $100 \mathrm{mg} \mathrm{L}^{-1}$ of PGa21Ca resulted in the removal of 96.95 of apparent color and residual turbidity of 1.84 NTU.

\section{ACKNOWLEDGMENTS}

This research was financed by the Brazilian research funding agencies Conselho Nacional de Desenvolvimento Cientifico e Tecnológico, Grant no. 400040/2016-6 (CNPq), Fundação de Amparo à Pesquisa do Estado de São Paulo, Grant no. 2015/02650-8 (FAPESP), and Instituto Granado de Tecnologia da Poliacrilonitrila (IGTPAN). All authors were involved in sample collection, drafting the article and discussed the results contributed to the final work.

\section{AUTHOR CONTRIBUTIONS}

All the authors of this article participated in collecting water samples from the Pinheiros River in São Paulo. Valquíria Campos guided and oversaw the fieldwork and created the manuscript dummy as well as Figure 2. Janaína M.F. Domingos was responsible for designing Figure 1 and the chemical tests. Diego N. Anjos took care of the preservation of samples, started the chemical tests, and produced the list of references. Vivian S. Lira also participated in the chemical tests, and in the construction of Table I. All the authors participated in the composition of the manuscript and in the discussion section, whose content they were in agreement with.

\section{REFERENCES}

APHA - AMERICAN PUBLIC HEALTH ASSOCIATION. 2012. Standard Methods for the Examination of Water and Wastewater, 22nd ed., Washington: American Water Works Association, Water Environment Federation.

BAJAJ I AND SINGHAL R. 2011. Poly (glutamic acid) - An emerging biopolymer of commercial interest. Bioresour Technol 102: 5551-5561.

BONDY SC. 2010. The neurotoxicity of environmental aluminum is still an issue. NeuroToxicology 31: 575-581.

CAMPOS V, FERNANDES ARAC, MEDEIROS TAM AND ANDRADE EL. 2016. Physicochemical characterization and evaluation of PGA bioflocculant in coagulationflocculation and sedimentation processes. J Environ Chem Eng 4: 3753-3760.

CONAMA - CONSELHO NACIONAL DE MEIO AMBIENTE. 2005. Resolução $\mathrm{n}^{\circ}$ 357, de 17 de março de 2005 , dispõe sobre a classificação dos corpos de água e diretrizes ambientais para o seu enquadramento, bem como estabelece as condições e padrões de lançamento de efluentes, e de outras providências. Disponível em: http:// www.mma.gov.br/port/conama/res/res05/res35705.pdf. Acesso em: 7 Junho de 2017.

CUNHA DGF, GRULL D, DAMATO M, BLUM JRC, LUTTI JEI, EIGER S AND MANCUSO PCS. 2010. On site flotation for recovering polluted aquatic systems. Water SciTechnol 62(7): 1603-1613.

DZULFAKAR MA, SHAHARUDDIN MS, MUHAIMIN AA AND SYAZWAN AI. 2011. Risk assessment of aluminum in drinking water between two residential areas. Water 3: 882-893. 
GUIMARÃES NR. 2017. Impacto da Coagulação Química na Remoção de Compostos Orgânicos em Efluente Tratado por Processo de Lodos Ativados. (Tese de Doutorado), São Paulo.

HUANG X, SUN S, GAO B, YUE Q, WANG Y AND LI Q. 2015. Coagulation behavior and floc properties of compound bioflocculant-polyaluminum chloride dualcoagulants and polymeric aluminum in low temperature surface water treatment. J Environ Sc 30: 215-222.

ISO 5667-3 - INTERNATIONAL ORGANIZATION FOR STANDARDIZATION. 2012. Water Quality - Sampling Part 3: Preservation and Handling of Water Samples.

PRITCHARD M, CRAVEN T, MKANDAWIRE T, EDMONDSON AS AND O'NEILL JG. 2010. A comparison between Moringa oleifera and chemical coagulants in the purification of drinking water - An alternative sustainable solution for developing countries. Phys Chem Earth 35: 798-805.
ROCHA AA. 1991. Do lendário Anhembi ao poluído Tietê. São Paulo, EDUSP.

SHIH IL, VAN YT, YEH LC, LIN HG AND CHANG YN. 2011. Production of a biopolymer flocculant from Bacillus licheniformis and its flocculation properties. Bioresour Technol 78: 267-272.

SUNG MH, PARK C, KIM CJ, POO H, SODA K AND ASHIUCHI M. 2005. Natural and edible biopolymer poly$\gamma$-glutamic acid: Synthesis, production, and applications. Chem Rec 5: 352-366.

USEPA - U.S. ENVIRONMENTAL PROTECTIONAGENCY. 2018. Surface Water Quality Standards - Chapter 62302. Available at: https://www.epa.gov/sites/production/ files/2014-12/documents/fl_section62-302.pdf. Accessed January 6, 2018.

YOKOI H, ARIMA T, HIROSE J, HAYASHI S AND TAKASAKI Y. 1996. Flocculation properties of poly (gamma glutamic acid) produced by Bacillus subtilis. J Ferment Bioengineer 82(1): 84-87. 